\title{
The Chautauqua Moment
}

Religion and American Culture 
The Religion and American Culture series explores the interaction between religion and culture throughout American history. Titles examine such issues as how religion functions in particular urban contexts, how it interacts with popular culture, its role in social and political conflicts, and its impact on regional identity. Series Editor Randall Balmer is the Ann Whitney Olin Professor of American Religion and former chair of the Department of Religion at Barnard College, Columbia University.

Michael E. Staub, Torn at the Roots: The Crisis of Jewish Liberalism in Postwar America. Clyde R. Forsberg, Jr., Equal Rites: The Book of Mormon, Masonry, Gender, and American Culture.

Amy DeRogatis, Moral Geography: Maps, Missionaries, and the American Frontier. Julie Byrne, $O$ God of Players: The Story of the Immaculata Mighty Macs.

Arlene Sanchez-Walsh, Latino Pentecostal Identity: Evangelical Faith, Self, and Society. 


\title{
The Chautauqua Moment
}

\author{
Protestants, Progressives, and the Culture of \\ Modern Liberalism
}

Andrew C. Rieser

Columbia University Press

New York 
Columbia University Press

Publishers Since i 893

New York, Chichester, West Sussex

Copyright (C) 2003 Columbia University Press

All rights Reserved

\section{Library of Congress Cataloging-in-Publication Data \\ Rieser, Andrew C.}

The Chautauqua moment : Protestants, progressives, and the culture of modern liberalism / Andrew C. Rieser p. cm.

Includes bibliographical references and index ISBN: 978-0-23 I-I 2642-7 (cloth : alk. paper)

I. Chautauquas-United States-History.

2. Protestant churches-Education-United States-History.

3. Middle class-Education-United States-History.

LC655 I .R54 2003

$374 / .973-\mathrm{dc} 2 \mathrm{I}$

2003046004

Columbia University Press books are printed on permanent and durable acidfree paper

Printed in the United States of America

References to Internet Web Sites (URLs) were accurate at the time of writing. Neither the author nor Columbia University Press is responsible for

Web sites that may have expired or changed since the time of writing 
For Matthew 
